\title{
Beberapa Metode pada Masalah Pemrograman Stokastik
}

\author{
Ihda Hasbiyati ${ }^{1}$, Hasriati ${ }^{2}$ \\ Matematika FMIPA Universitas Riau ${ }^{1}$, ihdahasbiyati@ gmail.com ${ }^{1}$ \\ Matematika FMIPA Universitas Riau' ${ }^{2}$, hasriati.hasri@gmail.com²
}

DOI:https://doi.org/10.15642/mantik.2017.3.2.83-86

\begin{abstract}
Abstrak
Masalah pemrograman stokastik adalah masalah pemrograman matematis (linier, integer, mixed integer, dan nonlinier) dengan elemen stokastik berada dalam data. Untuk mendapatkan solusi layak dan optimal dengan datanya stokastik dibutuhkan beberapa metode. Metode-metode yang bisa diterapkan dalam masalah pemrograman stokastik diantaranya metode dekomposisi L-Shape dan metode lagrange. Setiap metode dapat menentukan solusi optimal untuk menyelesaikan masalah pemrograman stokastik.
\end{abstract}

Kata kunci: Masalah pemrograman stokastik, optimisasi robust, chance-constrained, recourse-based stochastic.

\begin{abstract}
Stochastic programming problem is mathematical problem (linear, integer, mixed integer, and nonlinier) with stochastic element lies data. To get reasonable solution and optimal with its stochastic data is needed several method. Applicable method in trouble stochastic programming are L-Shape decomposition and lagrange decomposition. Each method can determine optimal solution to troubleshoots stochastic programming
\end{abstract}

Keywords: Stochastic programming problems, robust optimization, chance-constrained programming, recourse stochastic programming

\section{Pendahuluan}

Pemograman stokastik adalah pemograman matematik dimana semua data yang tergabung ke dalam fungsi tujuan dan fungsi kendalanya berbentuk ketidakpastian. Ketidakpastian ini dicirikan dengan distribusi probabilitas pada parameternya. Walaupun ketidakpastian terdefinisi secara tepat, namun dalam prakteknya harus disusun secara terperinci dengan beberapa scenario sebagai akibat yang mungkin dari data, juga dalam spesifikasi dan ketepatan distribusi gabungan peluang.

Masalah pemrograman stokastik berbeda dengan masalah optimasi deterministik yang dirumuskan dengan parameter-parameter yang diketahui, dalam masalah di dunia nyata selalu memasukkan beberapa parameter-parameter yang tidak diketahui. Contohnya pada suatu perusahaan gas yang mempunyai rencana untuk dua tahun, pada tahun pertama perusahaan gas membeli gas dari pasar, pengiriman kepada konsumen dilakukan segera dan juga dilakukan penyimpanan untuk tahun berikutnya. Variabelvariabel yang mempengaruhi keputusan untuk mencadangkan penyimpanan atau membeli dari pasar diantaranya: berapa banyak gas yang dibeli untuk pengiriman, berapa banyak gas yang dibeli untuk penyimpanan, berapa banyak gas yang diambil dari penyimpanan dan pembelian untuk konsumen. Keputusan bergantung kepada harga gas pada tahun pertama dan tahun kedua, biaya penyimpanan, ukuran kapasitas penyimpanan dan permintaan pada setiap periode.Aplikasi lain dari pemrograman stokastik diantaranya adalah pada perencanaan produksi, penjadwalan, pembuatan rute, pengalokasian, kontrol dan manajemen lingkungan, finansial dan lain-lain.

Beberapa penelitian yang telah dilakukan 
peneliti terhadap pemrograman stokastik diantaranya, oleh Julia L. Higle pada tahun 1991 yang menggunakan dekomposisi benders dengan variabel random pada fungsi tujuan, padatahun 1997 Andrzej Ruszczynski meneliti metode dekomposisi dengan menggunakan metode dekomposisi stokastik, pada tahun $2000 \mathrm{X}$. Chen meneliti metode newton dengan fungsi tujuannya membutuhkan ekpektasi dan tidak mempunyai turunan, pada tahun 2006 Jeff Linderoth meneliti metode sampling dengan menggunakan metode dekomposisi untuk pemrograman stokastik duatahap dengan recourse.

Masalah pemrograman stokastik dapat dibedakan menjadi dua, yaitu masalah pemrograman stokastik linier dan masalah pemrograman stokastik nonlinier. Masalah pemrograman stokastik linier adalah masalah pemrograman stokastik dengan fungsi tujuan dan fungsi kendalanya adalah fungsi-fungsi linier, sedangkan masalah pemrograman stokastik nonlinier adalah masalah pemrograman stokastik dengan salah satu atau keduanya dari fungsi tujuan dan fungsi kendalanya berbentuk fungsi nonlinier.

Untuk masing-masing masalah pemrograman stokastik baik linier ataupun nonlinier menggunakan pendekatan metode yang berbeda-beda. Metode pendekatan yang dilakukan berasal dari metode-metode yang dipakai untuk menyelesaikan masalah pemrograman matematik (linier dan nonlinier), diantaranya:

1. Untuk masalah pemrograman linier digunakan metode simpleks dan metode dekomposisi, metode dekomposisi dual.

2. Untuk masalah pemrograman nonlinier digunakan metode cutting-plane, metode descent, metode penalty dan metode lagrange.

Tulisan ini merupakan hasil kajian dari beberapa metode penyelesaian masalah pemrograman matematis yang dipakai untuk masalah pemrograman stokastik.

\section{Kajian Teori}

Sebelum membahas masalah pemrograman stokastik, terlebih dahulu dibahas perubahan bentuk model dari masalah pemrograman matematik menjadi masalah pemrograman stokastik.

Misalkan masalah pemrograman linier sebagai berikut

$$
\left.\begin{array}{c}
\min \left\{c_{1} x_{1}+c_{2} x_{2}+\cdots+c_{n} x_{n}\right\} \\
\text { kendala, } \\
a_{11} x_{1}+a_{12} x_{2}+\cdots+a_{1 n} x_{n}=b_{1} \\
a_{21} x_{1}+a_{22} x_{2}+\cdots+a_{2 n} x_{n}=b_{2} \\
\vdots \\
a_{m 1} x_{1}+a_{m 2} x_{2}+\cdots+a_{m n} x_{n}=b_{m} \\
x_{1}, x_{2}, \cdots, x_{n} \geq 0
\end{array}\right\}
$$

Dengan menggunakan notasi matriks persamaan (1) dapat dituliskan kembali sebagai berikut

$$
\left.\begin{array}{c}
\min c^{T} x \\
\text { kendala } \\
\begin{array}{c}
\text { x }=b \\
x \geq 0
\end{array}
\end{array}\right\}
$$

Persamaan (2) dapat dituliskan kembali dalam bentuk umum sebagai berikut

$\left.\begin{array}{c}\min g_{0}(x) \\ \text { kendala, }, g_{i}(x) \leq 0, i=1, \cdots, m \\ x \in X \subset \mathbb{R}^{n}\end{array}\right\}$

Himpunan $X$ mempunyai sifat yang sama dengan fungsi $g_{i}: \mathbb{R}^{n} \rightarrow \mathbb{R}, i=0, \cdots, m$. Fungsi $g_{i}$ dan himpunan $X$ disebut pemrogramam linier atau nonlinier apabila:

1. Linier, jika $X$ adalah himpunan konvek dan fungsi $g_{i}: \mathbb{R}^{n} \rightarrow \mathbb{R}, i=0, \cdots, m$ linier.

2. Nonliner, jika paling sedikit satu dari fungsi $g_{i}: \mathbb{R}^{n} \rightarrow \mathbb{R}, i=0, \cdots, m$ nonlinier atau $X$ bukan himpunan konvek, dengan ketentuan sebagai berikut

a. Konveks, jika $X \cap\left\{x \mid g_{i}(x) \leq 0, i=\right.$ $1, \cdots, m\}$ adalah himpunan konveks dan $g_{0}$ adalah fungsi konveks,

b. Nonkonveks, jika tidak ada dari $X \cap$ $\left\{x \mid g_{i}(x) \leq 0, i=1, \cdots, m\right\}$ yang bukan konveks atau fungsi objektif $g_{0}$ bukan konveks.

Persamaan (3) dapat dituliskan dalam bentuk masalah pemrograman stokastik dengan menambahkan parameter random $\tilde{\xi}$ sebagai berikut

$$
\left.\begin{array}{c}
\min g_{0}(x, \xi) \\
\text { kendala, } g_{i}(x, \xi) \leq 0, i=1, \cdots, m, \\
x \in X \subset \mathbb{R}^{n}
\end{array}\right\}
$$

Pada persamaan (4) ditambahkan suatu fungsi recourse untuk memastikan bahwa setiap pemilihan vektor random $\xi$ menjamin tidak 


\section{JURNAL MATEMATIKA "MANTIK" \\ Edisi: Oktober 2017. Vol. 03 No. 02}

ISSN: 2527-3159

E-ISSN: 2527-3167

terjadinya pelanggaran yang dapat mengakibatkan biaya ekstra perunit, sehingga persamaan dapat dituliskan kembali sebagai berikut

$$
\left.\begin{array}{c}
\min f_{0}(x, \xi)=g_{0}(x, \xi)+Q(x, \xi) \\
\text { kendala, } g_{i}(x, \xi) \leq 0, i=1, \cdots, m, \\
x \in X \subset \mathbb{R}^{n}
\end{array}\right\}
$$

Fungsi recourse pada persamaan (5) yaitu

$$
Q(x, \xi)=\min _{y}\left\{q^{T} y \mid W_{y} \geq g^{+}(x, \xi), y \in Y\right\}
$$

dengan $g^{+}(x, \xi)=\left(g_{1}^{+}(x, \xi), \cdots, g_{m}^{+}(x, \xi)\right), y \in$ $Y \subset \mathbb{R}^{\bar{n}}$ adalah vektor recourse dengan $\{y \mid y \geq 0\}$, $W$ adalah matriks berukuran $m \times \bar{n}$, dan $q \in \mathbb{R}^{\bar{n}}$ adalah vektor unit biaya.

\section{Hasil dan Pembahasan}

Metode yang dipakai untuk meyelesaikan masalah pemrograman matematik (linier dan nonlinier) seperti metode simpleks, metode dekomposisi, metode dekomposisi dual, metode cutting-plane, metode descent, metode penalty dan metode lagrange dapat dilihat pada [3], [4], dan [5]. Metode-metode yang dipakai pada masalah pemrograman matematik dapat juga digunakan pada masalah pemrograman stokastik karena pada dasarnya pemrograman stokastik adalah pemrograman matematik.

Salah satu pengembangan dari metode pada pemrograman matematik yaitu metode lagrange yang dipakai untuk masalah pemrograman nonlinier stokastik, yang diberikan sebagai berikut,

Misalkan program nonlinier stokastik dengan recourse diberikan sebagai berikut:

$$
\min _{x \in X} \hat{c}_{0}(x)+\mathrm{E}_{\xi_{1}} Q_{1}\left(\mathrm{x}, \xi_{1}\right)
$$

Fungsi recourse:

$$
Q_{1}\left(x, \hat{\xi}_{1}\right)=\min _{y_{1}} q_{1}\left(x, y_{1}, \hat{\xi}_{1}\right)+E_{\xi_{2}} Q_{2}\left(x, y_{1}, \hat{\xi}_{1}, \xi_{2}\right)
$$

kendala $c_{1}\left(x, y_{1}, \hat{\xi}_{1}\right)=0$

Dan untuk $t=2, \cdots, T-1$, berulang dipunyai

$$
\begin{aligned}
& \mathcal{Q}_{t}\left(x, y_{1}, \cdots, y_{t-1}, \hat{\xi}_{1}, \cdots, \hat{\xi}_{t}\right) \\
& =\min _{y_{t}} q_{t}\left(x, y_{1}, \cdots, y_{t-1}, \hat{\xi}_{1}, \cdots, \hat{\xi}_{t}\right) \\
& +E_{\xi_{t+1}} Q_{t+1}\left(x, y_{1}, \cdots, y_{t-1}, \hat{\xi}_{1}, \cdots, \hat{\xi}_{t}, \hat{\xi}_{t+1}\right) \\
& \quad \text { s.t. } c_{1}\left(x, y_{1}, \cdots, y_{t}, \hat{\xi}_{1}, \cdots, \hat{\xi}_{t}\right)=0
\end{aligned}
$$

$\mathcal{Q}_{T}=0, x \in \Re^{n_{0}}$ adalah vektor deterministik, $\hat{\xi}_{i}$ adalah realisasi dari vektor random $\xi_{i} \cdot y_{i} \in \mathfrak{R}^{n_{i}}$ yang merupakan vektor keputusan padatahap ke$i$, yang dibangun secara rekursif oleh $x, y_{1}, \cdots, y_{i-1}$ dan $\hat{\xi}_{1}, \cdots, \hat{\xi}_{i}$, dalam hal ini $y_{i}\left(x, y_{1}, \cdots, y_{i-1}, \hat{\xi}_{1}, \cdots, \hat{\xi}_{i}\right)$ direpresentasikan secaraaktual. $\hat{c}_{0}$ dan $c_{0}$ adalah fungsi bernilai riil pada $\Re^{n_{0}}$. $c_{t}$ random karena berelasi dengan $\hat{\xi}_{1}, \cdots, \hat{\xi}_{t}$. Untuk vektor random diskrit $\xi=$ $\left(\xi_{1}, \cdots, \xi_{T-1}\right)$, jika $c_{t}$ mempunyai realisasi hingga $c_{i t}\left(i=1, \cdots, S_{t}\right)$, maka semua $c_{t i}$ bentuk fungsi konstrain pada tahap $t$, model pada persamaan (6) merujuk kepada model yang ada pada [1] dan [2]. Proses penyelesaian masalah pemrograman nonlinear stokastik pada persamaan (6) dimulai dengan barisan "iterasi major", pada setiap barisan iterasi major, konstrain nonlinier dilinierisasi pada beberapa titik dasar $x_{k}$ dan ketaklinieran didampingkan dengan fungsi objektif dengan pengali Lagrange, kemudian definisikan, $\tilde{f}\left(x, x_{k}\right)=f\left(x_{k}\right)+J\left(x_{k}\right)\left(x-x_{k}\right)$, dimana $J_{k}=\left[J\left(x_{k}\right)\right]_{i j}=\partial f^{i} / \partial x_{j}$ adalah matriks Jacobian dari turunan parsial pertama dari fungsi konstrain. Selanjutnya selesaikan sub-problem linier berikut untuk iterasi major ke-k, sehingga diperoleh

Minimize $_{x y}$

$$
L\left(x, y, x_{k}, \lambda_{k}, \rho\right)=F(x)+d^{T} y-\lambda_{k}^{T}(f-\tilde{f})+\frac{1}{2} \rho(f-\tilde{f})^{T}(f-\tilde{f})
$$$$
\text { s.t } J_{k} x+A_{1} y=b_{1}+J_{k} x_{k}-f\left(x_{k}\right)
$$$$
A_{2} x+A_{2} y=b_{2}
$$$$
l \leq\left[\begin{array}{l}
x \\
y
\end{array}\right] \leq u
$$

Fungsi objektif pada Persamaan (7) adalah modifikasi Lagrangian augmented, dimana parameter penalty $\rho$ mempertinggi sifat konvergen dari estimasi awal derajat optimum paling jauh. Estimasi pengali Lagrangian $\lambda_{k}$ diperoleh sebagai nilai optimum pada solusi subproblem sebelumnya. Sepanjang pendekatan barisan iterasi major, optimum (diukur dengan pertukaran relatif pada estimasi berurut dari $\lambda_{k}$ dan degree untuk konstrain nonlinier yang dipenuhi pada $x_{k}$ ), parameter penalty $\rho$ direduksi menjadi nol dan kuadrat nilai konvergen dari subproblem dipenuhi untuk mencapai kondisi optimum. 
Metode lain pada pemrograman matematis yang dapat dikembangkan pada pemrograman stokastik yaitu metode dekomposisi dual yang dikembangkan menjadi metode dekomposisi LShape. Proses dimulai dengan membuat bentuk dual dari masalah pemrograman pada persamaan (2) menjadi sebagai berikut

$$
\max b^{T} u
$$

dengan kendala $A^{T} u \leq c$ dan $u \geq 0$

Selanjutnya diberikan fungsi recouse sebagai berikut:

$$
\begin{gathered}
Q(x, \xi)=\min \left\{q(\xi)^{T} y \mid W_{y}=h(\xi)-T(\xi) x, y\right. \\
\geq 0\}
\end{gathered}
$$

Dengan $h(\xi)=h_{0}+H \xi=h_{0}+\sum_{i} h_{i} \xi_{i}$ adalah vector yang bergantung pada vector random $\xi$. $T(\xi)=T_{0}+\sum_{i} T_{i} \xi_{i}$ adalah matriks deterministic dan $q(\xi)=q_{0}+\sum_{i} q_{i} \xi_{i}$. Selanjutnya periksa $h(\xi)-T(\xi) x$ sehingga masalah pemrograman stokastik feasible (layak). Solusi optimal diperoleh apabila dipenuhi kondisi $h(\xi)-$ $T(\xi) x=h_{0}-T_{0} x$, artinya $Q(x, \xi)$ linier dan konkaf pada $\xi$.

\section{Penutup}

Masalah pemrograman stokastik adalah juga masalah pemrograman matematis yang melibatkan parameter ketidakpastian. Metodemetode yang dipakai pada masalah pemrograman matematik juga dapat digunakan pada masalah pemrograman stokastik dengan melakukan pengembangan. Masing-masing metode mempunyai syarat kondisi optimal yang berbedabeda sesuai dengan bentuk model yang digunakan.

\section{Referensi}

[1] Ihda Hasbiyati. Simple Technique of Projected lagrange for a Class of Multi-Stage Stochastic Nonlinear Programs. Global Journal of Technology \& Optimization. Volume 6. Issue 3. (2015).

[2] Ihda Hasbiyati. A Projected Lagrangian Approach for a Class of Multi-Stage Stochastic Nonlinear Programs. Prociding Conferenceof the International Federation of Operational research Societies (IFORS). Melbourne Convention and Exhibition Centre, Melbourne, Australia. (2011)
[3] Peter kall, dan Janos Mayer. Stochastic Linear programming, Spriger, New York.(2005)

[4] Peter kall, dan Stein W. Wallace. Stochastic Programming, Springer, New York.(1994)

[5] M.S. Bazaraa and C.M. Shetty..Nonlinear Programming, Theory and Algorithms, (2nd Ed.), John Wiley \& Sons, NewYork. (1993) 